\title{
Viral abundance and activity in the deep sub-seafloor biosphere
}

\author{
Mathias Middelboe ${ }^{1, *}$, Ronnie N. Glud ${ }^{2,3,4}$, Manuela Filippini ${ }^{1,5}$ \\ ${ }^{1}$ Section for Marine Biology, University of Copenhagen, Strandpromenaden 5, 3000 Helsingør, Denmark \\ ${ }^{2}$ Institute of Biology \& Nordic Center for Earth Evolution (NordCee), Southern Danish University, 5230 Odense M, Denmark \\ ${ }^{3}$ Greenland Climate Research Center (Co Greenland Institute of Natural Resources) Kivioq, Box 570, 3900 Nuuk, Greenland \\ ${ }^{4}$ Scottish Association for Marine Science (SAMS), Dunstaffnage Marine Laboratory, Dunbeg, Oban, Argyll PA37 1QA, UK
}

${ }^{5}$ Present address: Institute of Evolutionary Biology and Environmental Studies, University of Zürich, Winterthurerstr. 190, 8057 Zürich, Switzerland

ABSTRACT: Subsurface abundance and distribution of viruses and prokaryotes was determined along a depth profile, down to $96 \mathrm{~m}$ below seafloor (96 mbsf), at Challenger Mound from the Porcubine Seabight (IODP Expedition 307). Viral and prokaryotic abundance decreased exponentially with sediment depth from $1.0 \times 10^{8}$ viruses $\mathrm{cm}^{-3}$ and $3.8 \times 10^{6}$ cells $\mathrm{cm}^{-3}$ at $4 \mathrm{mbsf}$ to $4.9 \times 10^{6}$ viruses $\mathrm{cm}^{-3}$ and 9.8 $\times 10^{5}$ cells $\mathrm{cm}^{-3}$ at $96 \mathrm{mbsf}$. The age of the sediment ranges from ca. 0.5 million yr before present (Ma) at 4 mbsf to ca. $2 \mathrm{Ma}$ at $96 \mathrm{mbsf}$. Assuming that the decline in viral abundance with depth reflects a gradual decay of the viral assemblage over time, the estimated decay rate of the viral community is $1.2 \times 10^{-6} \pm 0.3 \times 10^{-6}(\mathrm{SD}) \mathrm{yr}^{-1}$, corresponding to $\mathrm{a}$ half-life of the viral community of $5.8 \times 10^{5} \mathrm{yr}$. Measurements of viral and prokaryotic change in abundance were performed in incubations of undiluted, but homogenized, sediment samples (13.3 and $79.8 \mathrm{mbsf}$ ) in anaerobic bags. Viral abundance decreased rapidly (decay rates of $0.010 \pm 0.002$ [SD] and $0.022 \pm 0.018$ [SD] $h^{-1}$, respectively) in the incubations, suggesting that homogenization exposed the viruses to degradation processes. We hypothesize that most of the deep subsurface viral communities inhabit a microenvironment where the viruses are protected against decay, and can therefore persist in undisturbed sediments for hundreds of thousands, perhaps even millions, of years.

KEY WORDS: Benthic viruses - Marine phages · Subsurface viruses · Viral decay · Sediment viruses · Viral ecology

Resale or republication not permitted without written consent of the publisher

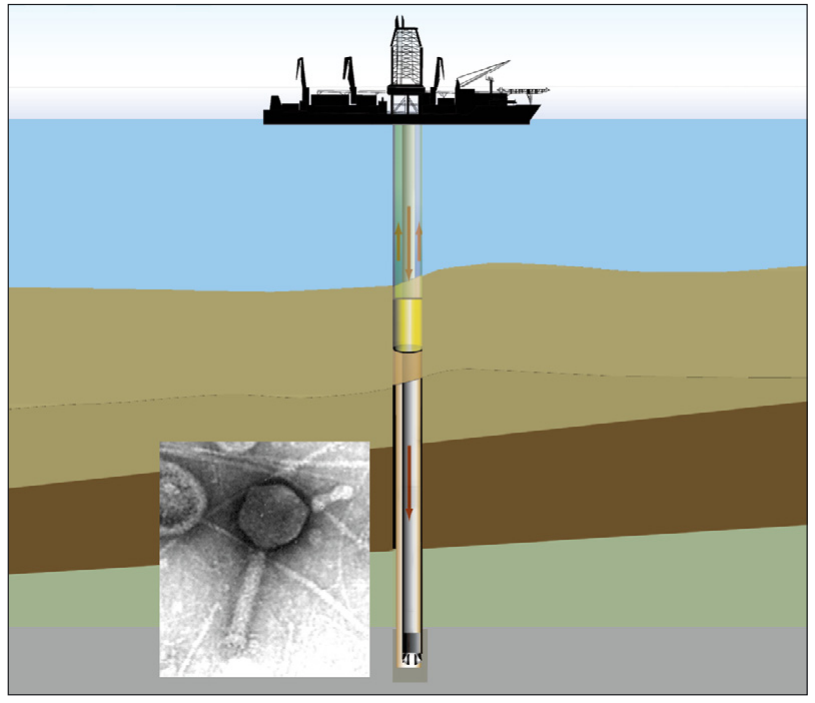

Advanced drilling technology allows sediment sampling several hundred meters into the deep subsurface biosphere. Inset: transmission electron micrograph of a benthic virus.

Graphic: Redrawn from an illustration by Greg Myers; Photo: Mathias Middelboe

\section{INTRODUCTION}

The deep sub-seafloor, extending from a few decimetres below the sediment surface to several hundred meters into the sediment, constitutes a giant sub-surface biosphere, which harbours more than half of all prokaryotic cells on Earth (e.g. Whitman et al. 1998, Schippers et al. 2005, Jørgensen \& Boetius 2007). Even in very old - ca.16 million yr (Ma) - and deep - more 
than $400 \mathrm{~m}$ below sea floor (mbsf) - sediments, a large fraction of the prokaryotes has been shown to be metabolically active with population turnover times of 0.25 to 22 yr (Schippers et al. 2005). Most of these cells have so far been resistant to cultivation, and little is known about the composition and diversity of this 'hidden majority' of Bacteria and Archaea (Whitman et al. 1998, Jørgensen \& Boetius 2007).

Viruses occur in high abundances $\left(10^{7}\right.$ to $10^{10}$ viruses $\mathrm{Cm}^{-3}$; e.g. Middelboe et al. 2006, Danovaro et al. 2008) in surface sediments and cause significant mortality of bacterial communities in these environments with large implications for bacterial activity and benthic nutrient cycling (e.g. Glud \& Middelboe 2004, Middelboe \& Glud 2006, Danovaro et al. 2008, Siem-Jørgensen et al. 2008). Production and abundance of viruses are closely correlated with benthic mineralization rates, and generally tend to decrease with sediment depth (Middelboe et al. 2003, 2006, Middelboe \& Glud 2006). As most studies of viruses in sediments have been performed in the upper sediment layer (0 to $10 \mathrm{~cm})$, little is known about the abundance, distribution and activity of viruses in the sub-seafloor biosphere.

To our knowledge, the only published study on the distribution of viruses in the deep biosphere is from an Ocean Drilling Project (ODP) sampling in Saanich Inlet, Canada. The results demonstrated high viral abundance $\left(>10^{9}\right.$ viruses $\left.\mathrm{g} \mathrm{dw}^{-1}\right)$ down to $>100 \mathrm{~m}$ into the sediment, but generally reflecting a decrease with depth (Bird et al. 2001). Saanich Inlet is an environment with relatively high sedimentation rates and the deep sediments are therefore relatively young (<14000 yr) compared with other ODP samplings. More recently, virus abundance and production were measured in the sediment at depths of 80 to $90 \mathrm{~cm}$ below the sediment surface in upwelling areas off Chile. Here, significant viral abundance $\left(8 \times 10^{7}\right.$ viruses $\mathrm{cm}^{-3}$ ) and production (ca. $2 \times 10^{6}$ viruses $\mathrm{cm}^{-3}$ $\mathrm{h}^{-1}$ ) were found, in spite of relatively low bacterial sulphate reduction rates at those depths (ca. $0.002 \mu \mathrm{mol}$ $\mathrm{SO}_{4} \mathrm{~cm}^{-3} \mathrm{~d}^{-1}$ ) (Middelboe \& Glud 2006).

The presence of viruses in the deep biosphere raises questions regarding their origin, fate and impact on the microbial community and their activity in this environment: How can large communities of viruses and prokaryotes persist in a compact, nutrient-deprived environment with extremely low metabolic activity, limited mobility and without input of organic matter? Is there sufficient energy available to sustain viral production in such an environment, or are the viruses found there remnants from an active surface sediment that has been buried? Our current knowledge of the fate of viruses in the deep biosphere does not provide clear answers to these questions. In fact, we are far from understanding even the basic strategies for microbial life, the persistence of prokaryotic and viral DNA and the interactions between microorganisms in the deep sub-seafloor biosphere. Exploration of these topics represents therefore an important challenge for future research.

The abundance of viruses in any environment is the net result of their production, decay and import/export processes. In sediments, viral production is primarily associated with the growth of Bacteria and Archaea, and viral particles are lost from the environment mainly by irreversible binding to particles and digestion by proteases and nucleases (e.g. Bales et al. 1991, England et al. 1998, Fischer et al. 2004). In surface sediments, the balance between production and decay varies with environmental factors, such as sedimentation events, fauna activity and temperature, and consequently, viral abundance may show temporal variations on both diurnal and seasonal scales (Fischer et al. 2003, SiemJørgensen et al. 2008). The relatively constant physical and chemical conditions at a given depth in the deep biosphere would imply that a given abundance of viruses reflects a long-term steady state between production and decay. However, the dynamics of the interactions between viruses and prokaryotes are unknown.

In the present study, we estimated the depth distribution of viral and bacterial abundance and the potential for stimulating their activity at selected depths in deep (4 to $96 \mathrm{mbsf}$ ) and old (ca. $2.5 \mathrm{Ma}$, Kano et al. 2007) sub-surface sediments. The results demonstrate the presence of ca. $5 \times 10^{6}$ viruses $\mathrm{cm}^{-3}$ in the old sediment collected at 96 mbsf and suggest that viruses may persist for hundreds of thousands of years in the deep biosphere.

\section{MATERIALS AND METHODS}

Study site and sample collection. The samples were collected from site U1317 during the Integrated Ocean Drilling Project (IODP) Expedition 307 on the eastern margin of the Porcupine Seabight. U1317 was located on Challenger Mound, a large cold-water coral bank, which extends $160 \mathrm{~m}$ above the seafloor and measures $0.55 \mathrm{~km}^{2}$ at its base (Huvenne et al. 2009). On board the ship, the cores were sectioned into subsamples for pore-water chemistry with a minimum resolution of $10 \mathrm{~cm}$. Sectioning and sealing of the samples was performed according to standard procedures for IODP sampling (Expedition 307 Scientists 2006), and the sealed samples for prokaryote and viral counts were stored at $4^{\circ} \mathrm{C}$ until further processing. Seven samples within a depth interval from 4 to 96.1 mbsf were allocated for analysis of viral and prokaryote abundance. In addition, incubations for viral and prokaryotic production were performed with samples from 13.3 and 79.8 mbsf. 
Sediment characteristics. Sediment porosity and total organic matter content were measured at all the selected depths. The porosity was calculated from the density and the weight loss after drying at $100^{\circ} \mathrm{C}$ for $24 \mathrm{~h}$, and showed a linear decrease with depth from 0.51 at 4 mbsf to 0.41 at 96.1 mbsf without significant correlation with viral $\left(\mathrm{r}^{2}=0.41, \mathrm{p}=0.12\right)$ or prokaryote $\left(\mathrm{r}^{2}=0.28, \mathrm{p}=0.22\right)$ abundance. Total organic matter content was measured as the weight loss after combustion at $450^{\circ} \mathrm{C}$ for $24 \mathrm{~h}$ (Buchanan 1984) and ranged from 1.4 to $2.6 \%$ dry weight with highest relative organic matter content in the deepest samples. This represents a standard procedure, but we cannot exclude contribution from carbonate compounds during combustion. Chemical data from pore-water analyses (Expedition 307 Scientists 2006) showed a linear increase in dissolved inorganic carbon (DIC) and ammonium concentrations with sediment depth from $2.5 \mathrm{mM}$ and zero, respectively in surface samples to $18 \mathrm{mM}$ DIC and $1.7 \mathrm{mM}$ ammonium at $100 \mathrm{mbsf}$, whereas sulphate concentrations decreased along the same gradient from $28 \mathrm{mM}$ to $10 \mathrm{mM}$. The temperature was relatively constant in the upper $100 \mathrm{mbsf}$, ranging between 11.0 and $13.5^{\circ} \mathrm{C}$ (Expedition 307 Scientists 2006).

Extraction and enumeration of prokaryotes and viruses. Sediment (4 g) was transferred to a sterile $50 \mathrm{ml}$ Falcon tube and $4 \mathrm{ml}$ of virus-free artificial seawater (34\%), $1 \mathrm{ml} 0.02 \mu \mathrm{m}$-filtered glutaraldehyde (3\% final concentration), and $1 \mathrm{ml}$ of sodium pyrophosphate (10 mM final concentration) were added. After $15 \mathrm{~min}$, the sample was sonicated $2 \times 1$ min on ice using a $60 \mathrm{~W}$ sonication probe (VibraCell ${ }^{\mathrm{TM}}$, Sonics \& Materials) and then centrifuged for $5 \mathrm{~min}$ at $700 \times \mathrm{g}$. The supernatant was collected and a further $2 \mathrm{ml}$ virus-free $(0.02 \mu \mathrm{m}$ filtered) seawater was added to the sample followed by mixing and centrifugation (as above) (Danovaro \& Middelboe 2010). The sample was washed 3 times using this procedure, and the total extracted volume (the supernatants) was pooled. For virus counts, 0.1 to $1 \mathrm{ml}$ of extract was immediately filtered onto a $0.02 \mu \mathrm{m}$ Anodisc filter (Whatman) and stained with SYBR Gold (Chen et al. 2001). For prokaryotes, a subsample of the extract ( 1 to $3 \mathrm{ml}$ ) was prestained with SYBR Gold for $5 \mathrm{~min}$ and subsequently filtered onto a $0.2 \mu \mathrm{m}$ black polycarbonate filter (Poretics). Prokaryotes and viruses were counted in 20 to 30 fields using epifluorescence microscopy at $1250 \times$ magnification.

There are a number of extraction procedures for viruses and prokaryotes in sediments (e.g. Fischer et al. 2005, Danovaro \& Middelboe 2010). In the present study, the sonicated sediment samples were initially processed through a centrifugation-based method with repeated steps of centrifugation and washes to reduce the background of sediment particles, which interferes with the counting of viruses by microscopy. Such centrifugation steps may result in an underestimation of viral and prokaryote abundances, since even low centrifugation may remove viruses and prokaryotes from the water phase (Siem-Jørgensen et al. 2008). Alternatively, a simpler dilution method can be used, where the sonicated sediment is diluted with virus-free water to avoid centrifugation of the sample (Velji \& Albright 1985, Siem-Jørgensen et al. 2008). The disadvantage of that method is that the higher background of organic and inorganic sediment particles may hide the fluorescently stained viruses and prokaryotes on the slide. The applicability of the different methods may therefore vary with the type of sediment and the density of viruses (Danovaro \& Middelboe 2010). Following the initial determination of viral and prokaryote abundance, we tested the applicability of the 2 procedures in 4 sediment samples from a parallel IODP core, to evaluate whether the centrifugation procedure was applicable to these deep sub-seafloor samples.

The tests showed that the dilution method yielded significantly higher values of both prokaryote and virus abundance compared to the procedure with precentrifugation (on average 10.9 \pm 3.6 , SD, and $5.3 \pm 3.4$ times higher, respectively; Fig. 1). Thus, despite a high background noise from organic and inorganic particles on the filter, the dilution method was the most appropriate to apply to these sediments. Our viral and

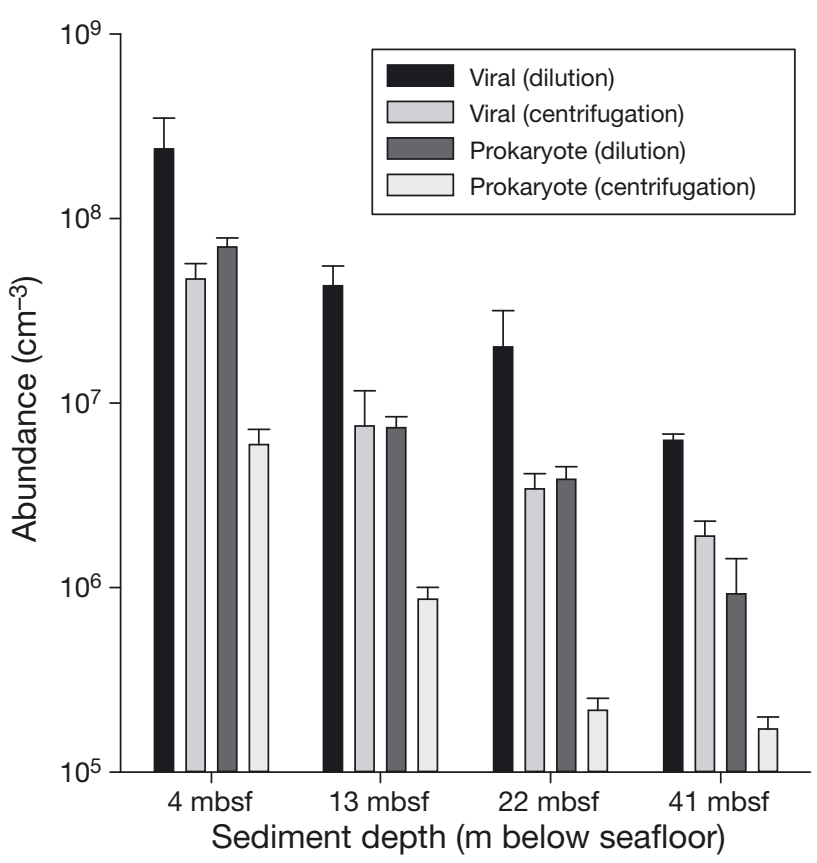

Fig. 1. Comparison of viral and prokaryote abundance in sediment samples obtained from 4 depths ( $4 \mathrm{~m}$ below seafloor [mbsf], 13 mbsf, 22 mbsf and 41 mbsf), using 2 different extraction methods (dilution and centrifugation). Error bars are $\pm \mathrm{SD}(\mathrm{n}=2)$ 
prokaryote counts, which were based on the centrifugation method, have been corrected accordingly. It should be noted that decompression during sampling may have affected the viral and prokaryotic counts obtained; however, this was not investigated.

Viral and prokaryotic production in anaerobic Würgler bag incubations. Anaerobic Würgler bag incubations (e.g. Hansen et al. 2000, Glud \& Middelboe 2004) were set up to investigate whether microbial growth in deep sediments could be stimulated by homogenization and elevated temperature (Wellsbury et al. 1997). Sealed samples from 13.3 and $79.8 \mathrm{mbsf}$ were opened under sterile conditions and homogenized using sterilized tools. Each sample was distributed into 2 sterile, gas-tight Würgler bags (Hansen et al. 2000) and incubated anaerobically for $60 \mathrm{~h}$ at $20^{\circ} \mathrm{C}$.

To avoid contamination, the Würgler bags were placed in a sterile plastic bag and placed inside a Laminar Air Flow (LAF) bench during incubation. After each sampling, the bags were transferred to a new, sterile plastic bag. Prior to and after each sampling the Würgler bags were sterilized on the outside with ethanol and all samplings took place in the LAF bench under sterile conditions. Bags were flushed with nitrogen (filtered through a $0.2 \mu \mathrm{m}$ filter) following each sampling. Samples for virus and prokaryote abundance were collected at time zero and then every 6 to $12 \mathrm{~h}$ for $60 \mathrm{~h}(0,6,12,24,36,48,60 \mathrm{~h})$.

\section{RESULTS AND DISCUSSION}

\section{Depth distribution of viral and prokaryote abundance}

The abundance of viruses decreased exponentially with depth from $1.0 \times 10^{8}$ viruses $\mathrm{cm}^{-3}$ at 4 mbsf to 4.9 $\times 10^{6}$ viruses $\mathrm{cm}^{-3}$ at $96 \mathrm{mbsf}\left(\mathrm{r}^{2}=0.996, \mathrm{p}<0.003\right)$ (Fig. 2). The prokaryote abundance overall also approximated an exponential decline with depth and ranged from $3.8 \times 10^{7}$ cells cm$^{-3}$ at 4 mbsf to $9.8 \times 10^{5}$ cells $\mathrm{cm}^{-3}$ at $96 \mathrm{mbsf}\left(\mathrm{r}^{2}=0.994, \mathrm{p}<0.02\right)$ (Fig. 2). The age constraints, geological structure and biogeochemistry of the sediments of the Challenger Mound have been described in previous publications from the IODP Expedition 307 (e.g. Kano et al. 2007, Webster et al. 2009). According to the strontium isotope stratigraphy, the sediment age ranges from $0.5 \mathrm{Ma}$ at $4 \mathrm{~m}$ to $1.0 \mathrm{Ma}$ at $20 \mathrm{mbsf}$. At $23.6 \mathrm{~m}$ a significant discontinuity from 1.0 to 1.7 Ma was discovered (horizontal line in Fig. 2) and below that the age of the sediment increased linearly to approximately $2 \mathrm{Ma}$ at $100 \mathrm{mbsf}$ (Kano et al. 2007). These sediments are therefore approximately 100 -fold older than at the site for the previous deep biosphere viral quantification (Bird et al. 2001). The



Fig. 2. Depth distribution and abundance of viruses and prokaryotes in the upper $96.1 \mathrm{~m}$ below seafloor (mbsf) of the deep sub-seafloor biosphere at the Challenger Mound. Error bars are $\pm \mathrm{SD}(\mathrm{n}=3)$. Horizontal line indicates a discontinuity at $23.6 \mathrm{~m}$, where the estimated sediment age changes from in 1.0 to 1.7 million yr

present study thus represents the first attempt to quantify viral abundance in such extremely old sediments.

The abundance of viruses found in the present study (ca. $10^{6}$ to $10^{8}$ viruses $\mathrm{cm}^{-3}$ ) was approximately 100 fold lower than that generally obtained from surface sediments (i.e. $10^{8}$ to $10^{10}$ viruses $\mathrm{cm}^{-3}$, Danovaro et al. 2008), and that found in the subsurface biosphere in Saanich Inlet (Bird et al. 2001). The virus:prokaryote (V:P) ratio ranged between 2 and 6 with no significant changes with depth ( $p>0.1$, ANOVA). This is similar to ratios obtained in the deep subsurface biosphere in Saanich Inlet (Bird et al. 2001) and in surface sediments (e.g. Siem-Jørgensen et al. 2008). The fact that the V:P ratio did not change systematically with sediment depth could be related either to similar decay rates for viruses and prokaryotes in the respective sediment layers or that relative prokaryotic mortality caused by virus infections is depth independent, or a combination of both.

Previous studies in surface sediments have demonstrated high virus production rates and a positive correlation between the activity of bacteria and the production of viruses (Glud \& Middelboe 2004, Danovaro et al. 2008). At the same time, a number of studies have suggested that all benthic environments contain a high and relatively stable background level of viruses, even in environments of low activity or during periods with marginal input of organic material (e.g. Middelboe \& Glud 2006, Siem-Jørgensen et al. 2008). For example, the viral abundance in a coastal sediment showed strong seasonal variation, both at the surface $(0$ to $0.5 \mathrm{~cm}$ ) and in deeper (6 to $10 \mathrm{~cm}$ ) sediment layers, 
which was coupled with the input of organic matter from the water column. In both sediment layers, however, viral abundance never fell below ca. $4 \times 10^{8}$ and ca. $2 \times 10^{8}$ viruses $\mathrm{cm}^{-3}$, respectively, even during periods with very low virus production (Siem-Jørgensen et al. 2008). In viral decay experiments, where viral production has been inhibited by for example $\mathrm{KCN}$, there is usually a relatively fast decay of a fraction of the community, whereas part of the community is often resistant to decay within a time frame of days to weeks (e.g. Fischer et al. 2004). Based on such evidence, we hypothesize that there is a fraction of the viral community which is practically inert and protected from decay under any given set of conditions in marine sediments. This is in line with more recent molecular and metagenomic studies, which have suggested that only a small fraction of benthic viral communities is present in high abundance (Breitbart et al. 2004, Filippini \& Middelboe 2007), whereas most of the viral gene pool consists of genomes occurring in small numbers, thus functioning as an inducible virus gene bank.

In contrast to earlier studies (e.g. Middelboe \& Glud 2006, Siem-Jørgensen et al. 2008), the applied incubation method did not allow an estimate of the potential for viral production (see Fig. 3). Hence, we do not have measurements of viral activity in the deep biosphere. The extremely low energy flux suggests that generation times for deeply buried prokaryotes range from years to thousands of years (Jørgensen \& Boetius 2007). Consequently, it is unlikely that there is sufficient energy available to sustain high viral production in these environments. However, measurements of ${ }^{3} \mathrm{H}$-thymidine (TdR) incorporation, as a measure of prokaryote activity, in the deep biosphere have shown high variability from 1 to $1000 \mathrm{fmol} \mathrm{cm}^{-3} \mathrm{~d}^{-1}$ (Parkes et al. 2000, Fry et al. 2008, Webster et al. 2009). Such data suggest that prokaryote activity in some deep biosphere environments may be sufficiently high to support a measurable production of viruses. Assuming (1) a prokaryote cell production of approximately $1 \times 10^{18}$ cells per mol of incorporated ${ }^{3} \mathrm{H}-\mathrm{TdR}$ (e.g. Deming \& Carpenter 2008), (2) that virus-induced mortality accounts for $6 \%$ of prokaryote production and (3) a virus burst size of 10 viruses per infection (Glud \& Middelboe 2004), viral production in the deep biosphere would range between $6 \times 10^{2}$ and $6 \times 10^{5}$ viruses $\mathrm{cm}^{-3}$ $\mathrm{d}^{-1}$. With an approximate average viral density of $1 \times$ $10^{7}$ viruses $\mathrm{cm}^{-3}$, the potential range in turnover time of the viral community would be from 0.03 to $32 \mathrm{yr}$. This range is quite similar to an estimated range of turnover time of 0.25 to $22 \mathrm{yr}$ for deep biosphere prokaryotes (Schippers et al. 2005). The assumptions behind these calculations (i.e. virus-induced mortality equal to $6 \%$ of prokaryote production and a virus burst size of 10) can be debated but seem reasonable. Virus- mediated bacterial mortality and virus burst size are correlated with the growth rate of the bacteria (e.g. Middelboe 2000), and values for the deep sub-seafloor biosphere must be in the lower end of the published range for sediments (e.g. burst sizes from 10 to 20 viruses per infection and a viral mortality impact of 6 to $40 \%$ of bacterial production (Glud \& Middelboe 2004).

In the present study, it is likely, therefore, that only a relatively small fraction of the total viral community of the investigated sediments is dynamically associated with prokaryote mortality and growth, whereas the majority of the community is an inactive reservoir of viruses with a long residence time. A background density of approximately $8 \times 10^{6}$ viruses $\mathrm{cm}^{-3}$ may very well represent a fraction of the viral community that is essentially non-degradable in this deep biosphere environment. On top of this, a smaller fraction of the viral assemblage may be more dynamic with faster rates of production and decay. According to Kano et al. (2007), there is a linear correlation between depth and age of the sediment from 0 to $20 \mathrm{~m}$ and again (below the unconformity at $23.6 \mathrm{mbsf}$ ) from 30 to 100 mbsf. Making the assumption that the decrease in viral abundance with depth reflects a constant exponential decay of the refractory background viral assemblage over time, the decay rate of this viral community is $1.2 \times 10^{-6} \pm 0.3 \times$ $10^{-6} \mathrm{yr}^{-1}$, corresponding to a half-life of the viral community of $5.8 \times 10^{5} \mathrm{yr}$. A similar calculation for the zone between 4 and 20 mbsf gives a decay rate of $1.7 \times 10^{-5} \pm$ $1.4 \times 10^{-5} \mathrm{yr}^{-1}$, and a half-life of $4.1 \times 10^{4} \mathrm{yr}$.

Consequently, we suggest that the majority of the viral particles observed in the deep biosphere represent extremely old viruses, which were produced several hundred thousand years ago in the upper $30 \mathrm{~m}$ of the sediment layer and subsequently became protected from decay and essentially permanently buried in the deep biosphere. However, this does not exclude some production and decay of viruses even in these very deep sediments, which occur at a time scale of months or even days, sustained by a small, but significant, prokaryote metabolism in the deep biosphere (e.g. Schippers et al. 2005).

\section{Viral decay in Würgler bag incubations}

The potential of stimulating the activity of prokaryotes and viruses in the deep biosphere was estimated by incubating subsamples of homogenized sediment from 13.3 and 79.8 mbsf at elevated temperature relative to in situ. The Würgler bag approach has previously been applied to estimate net production of benthic viruses and bacteria under anaerobic conditions by following changes in abundances of viruses and bacteria over time (Glud \& Middelboe 2004, Middel- 

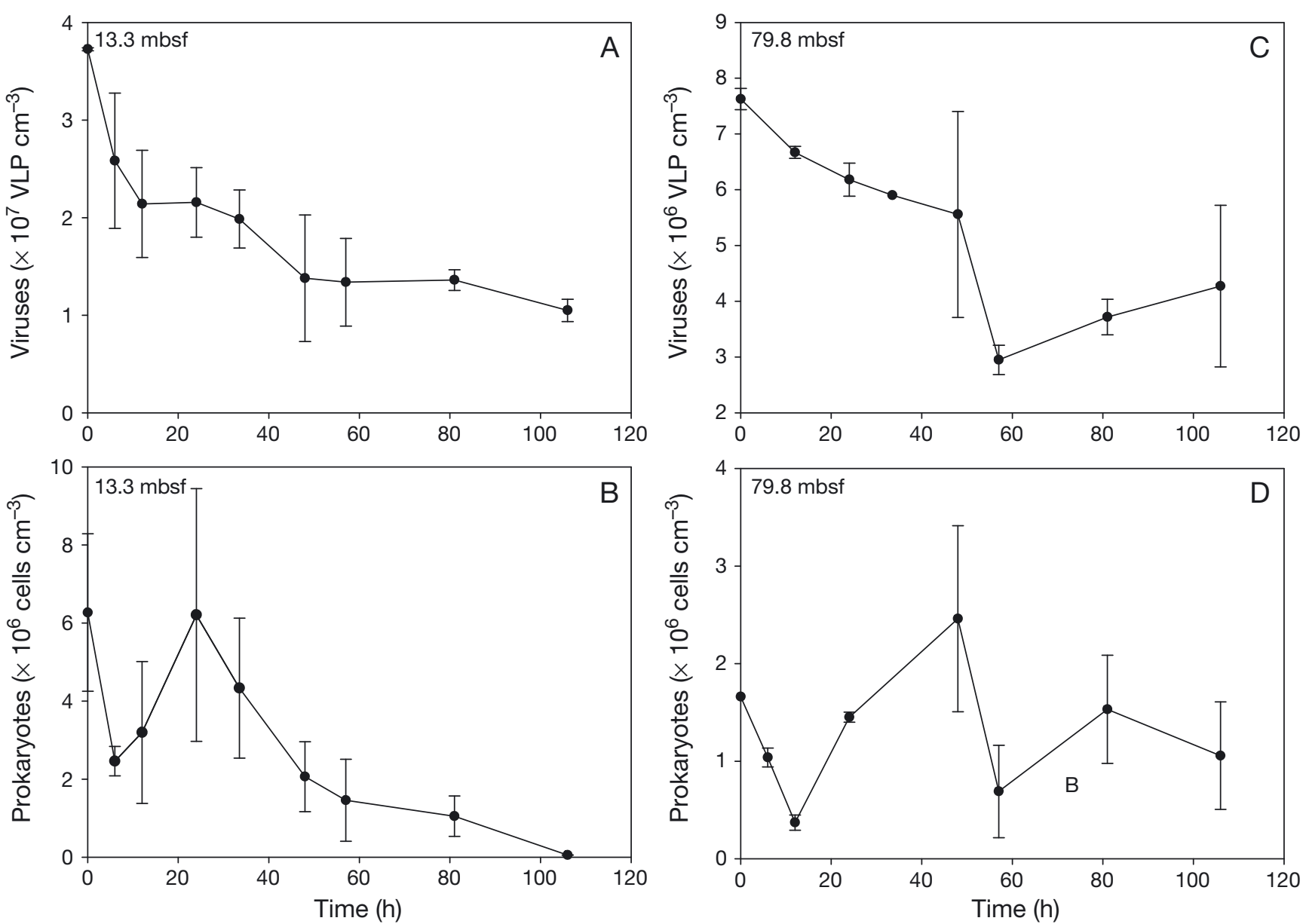

Fig. 3. Changes in the abundance of viruses and prokaryotes over time in duplicate anaerobic bag incubations with homogenized sediment collected from (A,B) $13.3 \mathrm{~m}$ below seafloor (mbsf) and (C,D) 79.8 mbsf. VLP: virus-like particles. Error bars are SD

boe \& Glud 2006, Middelboe et al. 2006, SiemJørgensen et al. 2008). In the present study, however, viral abundance decreased over time in incubations of homogenized sediment sampled from 13.3 and 79.8 mbsf (Fig. 3).

In both sets of incubations, viral abundance decreased exponentially (Fig. 3A,C) with average decay rates of $0.010 \pm 0.002\left(\mathrm{SD}\right.$, here and below) viruses $\mathrm{h}^{-1}$ $\left(\mathrm{r}^{2}=0.84, \mathrm{p}<0.001\right.$, ANOVA $)$ and $0.022 \pm 0.018 \mathrm{~h}^{-1}\left(\mathrm{r}^{2}=\right.$ $0.73, \mathrm{p}<0.02$, ANOVA) in the 13.3 and $79.8 \mathrm{mbsf}$ incubations, respectively. Prokaryote abundance exhibited an initial decrease followed by an increase of $2.1 \times 10^{5} \pm$ $0.3 \times 10^{5}$ cells cm ${ }^{-3} \mathrm{~h}^{-1}(\mathrm{p}=0.09$, ANOVA $)$ and $5.6 \times 10^{4}$ $\pm 1.2 \times 10^{4}$ cells cm${ }^{-3} \mathrm{~h}^{-1}(\mathrm{p}=0.13$, ANOVA $)$ at 13.3 and 79.8 mbsf, respectively, and a subsequent decline (Fig. 3B,D). This indicated a stimulation of prokaryotic activity in the incubations; however, the increase in cell abundance was not statistically significant.

The suggestion that virus production in the deep biosphere could be stimulated by increased prokaryote activity is not supported by these experiments. On the contrary, the perturbation of the sediment by homogenization resulted in relatively rapid decay of viruses. These results suggest that homogenization and incubation of the sediment exposes the viruses to degradation processes. Potentially, the exposure to proteases and nucleases in the sediment is the major cause of this rapid decay (Suttle \& Chen 1992, Noble \& Fuhrman 1997). These results support observations by Fischer et al. (2004) of a rapid viral decay in sediment samples associated with perturbations (e.g. slurrying and homogenization) of the samples. The authors suggested that handling of the sediment prior to the experiments increased the encounter probability between free enzymes and viruses in the sample, thus increasing enzymatic degradation of the viruses (Fischer et al. 2004). In addition, sediment mixing may have caused release of viruses from particles. Consequently, we cannot rule out that part of the observed decrease in viral abundance may have been associated with re-sorbing of transiently released viruses during the incubations. 
The presence of organic and inorganic particles has previously been shown to prolong persistence of viruses in marine environments (Mitchell \& Jannasch 1969, Gerba \& Schaiberger 1975). A protective effect of particles may be due either to a direct structural stabilization of particle-associated viruses or depend on adsorption of enzymes or other antagonistic factors, which promote inactivation of viruses (Gerba \& Schaiberger 1975). For the deep sediments analyzed here, the homogenization represents a strong perturbation of an environment which has remained undisturbed for several thousands of years. It is most likely, therefore, that the observed decay of viruses during incubation is the result of sediment handling, and does not represent the actual viral decay in the samples. Consequently, we hypothesize that a fraction of any benthic viral assemblage inhabits a microenvironment where the viruses are not exposed to decay and can therefore persist in undisturbed deep biosphere sediments for hundreds of thousands, perhaps even millions, of years (i.e. an estimated decay rate of $1.2 \times 10^{-6}$ $\left.\pm 0.310^{-6} \mathrm{yr}^{-1}\right)$. This may imply that virus-degrading enzymes can also be inactivated for a corresponding period of time and become reactivated by the applied perturbations of the sediment. Alternatively, stimulation of microbial activity by homogenization (e.g. Thamdrup \& Canfield 1996, Hansen et al. 2000) may have resulted in the production and release of extracellular enzymes, which may have contributed to viral decay.

Acknowledgements. We thank the captain and crew of the IODP 307 cruise for obtaining the samples. Jeanne Olsen's technical assistance is acknowledged. Funding was provided by the Danish Natural Sciences Research Council (FNU), The Carlsberg Foundation and The National Environmental Research Council (NERC) via 2 standard grants to R.N.G. (NE/F012691/1 and NE/F020406/1).

\section{LITERATURE CITED}

Bales RC, Hinkle SR, Kroeger TW, Stocking K, Gerba CP (1991) Bacteriophage adsorption during transport through porous media: chemical perturbations and reversibility. Environ Sci Technol 25:2088-2095

Bird DF, Juniper SK, Ricciardi-Rigault M, Martineu P, Prairie YT, Calvert SE (2001) Subsurface viruses and bacteria in Holocene/Late Pleistocene sediments of Saanich Inlet, BC: ODP holes 1033B and 1043B, Leg 169S. Mar Geol 174: 227-239

Breitbart M, Felts B, Kelley S, Mahaffy J, Nulton J, Salamon P, Rohwer F (2004) Diversity and population structure of a nearshore marine sediment viral community. Proc R Soc Lond Ser B Biol Sci 271:565-574

Buchanan JB (1984) Sediment analysis. In: Holme NA, McIntyre AD (eds) Methods for the study of marine benthos, 2nd edn. Blackwell Scientific, Oxford, p 41-64

> Chen F, Lu JR, Binder BJ, Liu YC, Hodson RE (2001) Application of digital image analysis and flow cytometry to enu- merate marine viruses stained with SYBR Gold. Appl Environ Microbiol 67:539-545

Danovaro R, Middelboe M (2010) Separation of free virus particles from sediments in aquatic systems. In: Wilhelm SW, Weinbauer MG, Suttle CA (eds) Manual of Aquatic Viral Ecology. ASLO, Waco, TX, p 74-81, available at www. aslo.org/boots/mave

Danovaro R, Corinaldesi C, Filippini M, Fischer UR and others (2008) Viriobenthos in freshwater and marine sediments: a review. Freshw Biol 53:1186-1213

> Deming JW, Carpenter SD (2008) Factors influencing benthic bacterial abundance, biomass, and activity on the northern continental margin and deep basin of the Gulf of Mexico. Deep-Sea Res II 55:2597-2606

England LS, Holmes SB, Trevors JT (1998) Review: persistence of viruses and DNA in soil. J Microbiol Biotechnol 14:163-169

Expedition 307 Scientists (2006) Site U1317. In: Ferdelman TG, Kano A, Williams T, Henriet JP, and the Expedition 307 Scientists (eds) Proc Integ Ocean Drilling Prog 307. Integrated Ocean Drilling Program Management International, Washington, DC. Available at http://publications. iodp.org/proceedings/307/104/104_.htm doi:10.2204/iodp. proc.307.104.2006

> Filippini M, Middelboe M (2007) Viral abundance and genome size distribution in the sediment and water column of marine and freshwater ecosystems. FEMS Microbiol Ecol 60:397-410

Fischer UR, Wieltschnig C, Kirschner AKT, Velimirov B (2003) Does virus-induced lysis contribute significantly to bacterial mortality in the oxygenated sediment layer of shallow oxbow lakes? Appl Environ Microbiol 69:5281-5289

Fischer UR, Weisz W, Wieltschnig C, Kirschner KT, Velimirov B (2004) Benthic and pelagic viral decay experiments: a model-based analysis and its applicability. Appl Environ Microbiol 70:6706-6713

> Fischer UR, Kirschner AKT, Velimirov B (2005) Optimization of extraction and estimation of viruses in silty freshwater sediments. Aquat Microb Ecol 40:207-216

Fry JC, Parkes J, Cragg BA, Weightman AJ, Webster G (2008) Prokaryotic biodiversity and activity in the deep subseafloor biosphere. FEMS Microbiol Ecol 66:181-196

> Gerba CP, Schaiberger GE (1975) Effect of particulates on virus survival in seawater. J Water Pollut Control Fed 47:93-103

> Glud RN, Middelboe M (2004) Virus and bacteria dynamics of a coastal sediment: implication for benthic carbon cycling. Limnol Oceanogr 49:2073-2081

> Hansen JW, Thamdrup B, Jørgensen BB (2000) Anoxic incubation of sediment in gas-tight plastic bags: a method for biogeochemical process studies. Mar Ecol Prog Ser 208:273-282

Huvenne VAI, Rooij DV, De Mol B, Thierens M, O'Donnell R, Foubert A (2009) Sediment dynamics and palaeo-environmental context at key stages in the Challenger cold-water mound formation: clues from sediment deposits at the mound base. Deep-Sea Res I 56:2263-2280

> Jørgensen BB, Boetius A (2007) Feast and famine - microbial life in the deep-sea bed. Natl Rev 5:770-781

Kano A, Ferdelman TG, Williams T, Henriet JP and others (2007) Age constraints on the origin and growth history of a deep-water coral mound in the northeast Atlantic drilled during Integrated Ocean Drilling Program Expedition 307. Geology 35:1051-1054

Middelboe M (2000) Bacterial growth rate and marine virushost dynamics. Microb Ecol 40:114-124

Middelboe M, Glud RN (2006) Viral activity along a trophic gradient in the continental margin sediments off central Chile. Mar Biol Res 2:41-51 
Middelboe M, Glud RN, Finster K (2003) Distribution of viruses and bacteria in relation to diagenetic activity in an estuarine sediment. Limnol Oceanogr 48:1447-1456

Middelboe M, Glud RN, Wenzhöfer F, Oguri K, Kitazato H (2006) Spatial distribution and activity of viruses in the deep-sea sediments of Sagami Bay, Japan. Deep-Sea Res I 53:1-13

Mitchell R, Jannasch HW (1969) Processes controlling virus inactivation in seawater. Environ Sci Technol 3:941-943

Noble RT, Fuhrman JA (1997) Virus decay and its causes in coastal waters. Appl Environ Microbiol 63:77-83

Parkes RJ, Cragg BA, Wellsbury P (2000) Recent studies on bacterial populations and processes in subseafloor sediments: a review. Hydrogeol J 8:11-28

Schippers A, Neretin LN, Kallmeyer J, Ferdelman TG, Cragg BA, Parkes RJ, Jørgensen BB (2005) Prokaryotic cells of the deep sub-seafloor biosphere identified as living bacteria. Nature 433:861-864

Siem-Jørgensen M, Glud RN, Middelboe M (2008) Viral dynamics in a coastal sediment: seasonal pattern, controlling factors and relations to the benthic-pelagic coupling. Mar Biol Res 4:165-179

Editorial responsibility: Gunnar Bratbak, Bergen, Norway
Suttle CA, Chen F (1992) Mechanisms and rates of decay of marine viruses in sea water. Appl Environ Microbiol 58: 3721-3729

> Thamdrup B, Canfield D (1996) Patways of carbon oxidation in continental margin sediments off central Chile. Limnol Oceanogr 41:1629-1650

Velji MA, Albright LJ (1985) Microscopic analysis enumeration of marine bacteria of seawater, marine sediment, fecal matter and kelp blade samples following pyrophosphate and ultrasound treatments. Can J Microbiol 32: 121-126

Webster G, Blazejak A, Cragg BA, Schippers A and others (2009) Subsurface microbiology and biogeochemistry of a deep, cold-water carbonate mound from the Porcupine Seabight (IODP Expedition 307). Environ Microbiol 11: 239-257

Wellsbury P, Goodman K, Barth T, Cragg BA, Barnes SP, Parkes RJ (1997) Deep marine biosphere fuelled by increasing organic matter availability during burial and heating. Nature 388:573-576

Whitman WB, Coleman DC, Wiebe WJ (1998) Prokaryotes: the unseen majority. Proc Natl Acad Sci USA 95:6578-6583

Submitted: April 5, 2010; Accepted: December 21, 2010

Proofs received from author(s): February 8, 2011 